\title{
Farklı Gıda Ürünlerinden İzole Edilen Laktik Asit Bakterilerinin Bazı Probiyotik Özelliklerinin Belirlenmesi
}

\author{
Melda Onur ${ }^{1}$, Harun Önlü ${ }^{*}$ \\ ${ }^{1}$ Muş Tarım ve Orman İl Müdürlüğ̈̈, Muş, Türkiye, (ORCID: 0000-0002-9082-223X), meldaonur@hotmail.com \\ 2 Muş Alparslan Üniversitesi Teknik Bilimler Meslek Yüksekokulu, Gıda İşleme Bölümü, Türkiye (ORCID: 0000-0003-3660-9267), h.onlu@,lparslan.edu.tr
}

(International Conference on Design, Research and Development (RDCONF) 2021 - 15-18 December 2021)

(DOI: 10.31590/ejosat.1041577)

\begin{abstract}
ATIF/REFERENCE: Onur, M \& Onlu, H. (2021). Farklı Gida Ürünlerinden İzole Edilen Laktik Asit Bakterilerinin Bazı Probiyotik Özelliklerinin Belirlenmesi. Avrupa Bilim ve Teknoloji Dergisi, (32), 562-572.

\section{$\ddot{O} z$}

Laktik asit bakterileri (LAB), heksoz şekerlerinin laktik aside fermantasyonu sürecinde önemli bir rol oynayan ticari olarak önemli bir organizma grubudur ve "genel olarak güvenli kabul edilen" olarak tanımlandıkları için endüstriyel uygulamalarda ve probiyotik olarak yaygın olarak kullanılan organizmalardır. Laktik asit bakterilerini (LAB) izole etmek için farklı gıda örnekleri toplanmış ve bu örneklerden 14 bakteri suşu saflaştırılmıştır. Morfolojik tanımlama için gram boyama, katalaz testi, metilen mavisi boyama, moleküler tanımlama için RAPD-PZR ve 16S rRNA gen dizileme yöntemleri kullanılmıştır. Ayrıca izolatlar, antibiyotik duyarlılığı, pepsin, pankreatin, safra tuzları, düşük $\mathrm{pH}$, bakteriyosin üretimi ve hemolitik aktivite altında hayatta kalma açısından karakterize edilmiş̧ir. 16S rRNA gen dizileme sonuçlarına göre izolatlar Lactobacillus sakei MH1, Lactococcus garvieae MH3, Enterococcus faeceium MH5, Pediococcus acidilactici MH10, Pediococcus acidilactici MH11, Pediococcus acidilactici MH12, Pediococcus acidilactici MH13 olarak belirlendi. Disk difüzyon testi sonuçları, izolatların tamamının kanamisine, çoğunun ise gentamisine dirençli olduğunu göstermektedir. MïK test sonuçları izolatların tamamının streptomisine dirençli olduğunu göstermektedir. Tüm suşlar bakteriyosin üretim testine göre indikatör mikroorganizmalara karşı antimikrobiyal etki göstermemiştir. Tüm suşların, pankreatin ve farklı safra tuzu $(\% 0.3, \% 0.5, \% 1)$ konsantrasyonunda hayatta kalabildiği tespit edilmiştir. Bu sonuçlara göre izolatlarımız gıda ve ilaç endüstrilerinde uygulama için probiyotik potansiyel adaylardır, ancak izolatların diğer probiyotik seçim kriterleri açısından taranması gerekmektedir.
\end{abstract}

Anahtar Kelimeler: Laktik Asit Bakterileri, Probiyotik, Antibiyotik Duyarlılı̆̆ı.

\section{Determination of Some Probiotic Properties of Lactic Acid Bacteria Isolated From Different Food Products}

\begin{abstract}
Lactic acid bacteria (LAB) are a group of commercially important organisms that play an important role in the fermentation process of hexose sugars into lactic acid and widely used in industrial applications and as probiotics since they were designated as "generally recognized as safe" organisms. In order to isolate lactic acid bacteria (LAB), different food samples were collected and 14 bacterial strains were purified from those samples. Gram staining, catalase test, methylene blue staining was used for morphologic identification, RAPD-PCR, and 16S rRNA gene sequencing methods were used for molecular identification. The isolates were characterized for antibiotic susceptibility, survival under pepsin, pancreatin, bile salts, low $\mathrm{pH}$, bacteriocin production, and hemolytic activity. According to the 16s rRNA gene sequence analysis isolates were designated as Lactobacillus sakei MH1, Lactococcus garvieae MH3, Enterococcus faeceium MH5, Pediococcus acidilactici MH10, Pediococcus acidilactici MH11, Pediococcus acidilactici MH12, Pediococcus acidilactici MH13. Disc diffusion test results show that all of the isolates were resistant to kanamycin, and most of resistant to gentamicin. MIC test results show that all of the isolates were resistant to streptomycin. No strains showed antimicrobial effect against indicator microorganisms according to the bacteriocin production test. All strains were able to survive in pancreatin and different bile salt $(\% 0.3, \% 0.5, \% 1)$ concentrations. According to these results, our isolates are probiotic potential candidates for the application in the food and pharmaceutical industries, however, isolates should be screened for furtherprobiotic selection criteria.
\end{abstract}

Keywords: Lactic Acid Bacteria, Probiotic, Antibiotic Susceptibility.

*Sorumlu Yazar: h.onlu@alparslan.edu.tr 


\section{Giriş}

Laktik asit bakterileri (LAB), laktik asit üretimiyle karakterize edilen ve birçok endüstriyel ya da geleneksel bitki, et ve süt fermantasyonunda baskın olan mikroorganizma grubudur. Ayrıca LAB, insan mide bağırsak sisteminin (GIT) doğal florasında bulunmaktadır ve ince bağırsaktaki baskın biota arasında kabul edilmektedir (Jensen ve ark., 2012; Marco ve ark., 2006; Yılmaz ve İpek 2021). LAB' nin çok uzun yıllardan beri fermente gıdaların üretiminde kullanılması ve bu gidalarla birlikte tüketilmesi LAB' nin genel olarak güvenli (GRAS= Generally regard as safety) kabul edilmesini sağlamıştır (Patil ve ark., 2010).

Süt ürünleri, etler, sebzeler, ekşi mayalı ekmek gibi ürünlerde bulunmalarının haricinde LAB; ağız boşluğu, vajina ve gastrointestinal sistem gibi insan mukozal yüzeylerinde de yaygın olarak bulunmaktadır. Metabolik faaliyetleri sonucu organik asitler, polioller, ekzopolisakkaritler ve antimikrobiyal bileşikler gibi birçok yararlı bileșiğin üretimi ile ilișkili olan LAB' nin gıdalardaki temel işlevi laktik asit üretimi ile asitliği arttırmaktır. Ayrıca LAB, aroma bileşenlerinin üretimi ile fermente gıdaların lezzet dokusuna ve besin değerine katkıda bulunur. Ek olarak patojen mikroorganizmaların inhibisyonuna katkıda bulunurlar ve böylece biyo-koruyucu kültürler olarak kullanılırlar. Bu nedenle LAB çok çeşitli fermente süt ürünleri, et, balık, meyve, sebze ve tahıl ürünlerinde gıda endüstrisinde starter kültür olarak kullanılır (Bintsis, 2018).

Probiyotikler, uygun miktarda alındıklarında konakçı sağlığı üzerinde faydalı etkiler sergileyen canlı mikroorganizmalardır (FAO ve WHO, 2002). En yaygin olarak kullanılan probiyotikler Lactobacillus ve Bifidobacterium suşlarıdır (Diosma ve ark., 2014; Fleet ve Balia, 2006). Bu mikrobiyal gruplar, insan vücudunda karşılaştıkları olumsuz koşullara dayanma (örneğin; tükrük enzimleri, düşük $\mathrm{pH}$ ve pankreas suyu), bağırsak epitel hücrelerine tutunma ve konağın GIT mikrobiyotasını düzenlenme yeteneğine sahiptir (de Melo Pereira ve ark., 2018; Liong ve ark., 2015; Marchesi ve ark., 2016; Mathur ve ark., 2020; Zoumpopoulou ve ark., 2017). Konağın, zararlı mikroorganizmalara karşı korunmasında önemli bir rol oynarlar ve ayrıca bağışıklık sistemini güçlendirirler (Agheyisi, 2008; Schultz, 2008; Soccol ve ark., 2010). Probiyotik mikroorganizmaların yüzyıllardır geleneksel olarak tüketilen fermente süt ürünleri ve fermente gidalarda mevcut olduğu bilinmektedir. Ayrıca gıda endüstrisinde fonksiyonel gıdaların üretiminde bir bileşen olarak kullanılmaktadır (Zucko ve ark., 2020). Probiyotik olarak kullanılan organizmalar içerisinde en önemli grubu laktik asit bakterileri (LAB) oluşturmaktadır. Bir mikroorganizmanın probiyotik olarak kabul edilebilmesi için insan vücudundaki olumsuz koşullara direnç, epitel hücrelere tutunma kabiliyeti, antimikrobiyal aktivite ve güvenlik değerlendirmesi dahil çeşitli kriterlere uygun olması gerekmektedir.

Bu çalışmada endüstri ve sağlık gibi alanlarda birçok öneme sahip laktik asit bakterileri farklı gıda kaynaklardan (fermente gıda ürünleri) izole edilerek tanımlanmıştır. Suş düzeyinde tanımlanmış bu bakterilerin bazı probiyotik özellikleri araştırılmıştır.

\section{Materyal ve Metot}

\subsection{Materyal}

Bu çalışmada kullanılan bakteri suşları Muş İlinden temin edilen farklı kaynaklardan (Muş kaşarı ve ev yapımı fermente ürünler gibi) izole edilmiştir. Çalışma kapsamında izole edilen suşlar MRS (de Man Rogosa Sharpe) sıvı besiyerinde $37^{\circ} \mathrm{C}$ 'de geliștirilerek stoğa alınmış ve çalışmanın ilerleyen aşamalarında kullanılmak üzere $-80^{\circ} \mathrm{C}$ ' de saklanmıştır.

\subsubsection{Farklı gıda kaynaklarından örneklerin toplanmast}

Gıda kaynaklı örneklerden aseptik koşullarda alınan numuneler, uygun koşullarda laboratuvar ortamına getirilerek Laktik asit bakterilerinin izolasyonu için kullanılmıştır. Laboratuvar ortamına getirilen gida örnekleri serum fizyolojik (SF) ile $10^{-8}$ seyreltme düzeyine kadar seri dilüsyona tabi tutulmuştur. $\mathrm{Bu}$ dilüsyonlardan $1000 \mu \mathrm{L}$ alınarak MRS agar üzerine yayma ekim yöntemiyle ekimleri yapılmış ve $37^{\circ} \mathrm{C}$ ' de 48 saat inkübasyona bırakılmıştır. Bu sürenin sonunda koloniler seçilerek steril öze yardımı ile MRS broth besiyerine aktarılmış ve $37^{\circ} \mathrm{C}$ 'de 24 saat inkübasyona bırakılmıştır. İnkübasyon süresi biten kültürlerin metilen mavisi ile basit boyamaları yapılarak 1 şı mikroskobunda saflıkları kontrol edilmiş ve saf olduğu belirlenen kültürden $500 \mu \mathrm{L}$ alınarak içerisinde $500 \mu \mathrm{L}$ steril gliserol bulunan eppendorf tüplere eklenmiş ve hazırlanan bakteri stokları diğer çalışmalarda kullanılmak üzere $-80^{\circ} \mathrm{C}$ ' de muhafaza edilmişstir.

\subsubsection{Katalaz Testi}

$-80^{\circ} \mathrm{C}^{\prime}$ de gliserol içerisinde muhafaza edilmiş olan stok kültürlerden $50 \mu \mathrm{L}$ alınıp $5 \mathrm{ml}$ ' lik MRS broth besiyerine aşılanmış ve 24 saat boyunca $37^{\circ} \mathrm{C}$ 'de inkübasyona bırakılmıştır. Bakteri gelişimi gözlenen sıvı kültürlerden alınan bakteriler MRS agar üzerine çizgi ekim yöntemi ile aktarılmış ve $37^{\circ} \mathrm{C}$ ' de 24 saat geliştirilmiştir. Gelişen koloniler temiz bir lam üzerine steril öze yardımı ile yayılmış ve kolonilerin üzerine $\mathrm{H}_{2} \mathrm{O}_{2}$ damlatılarak gaz çıkışının gerçekleşip gerçekleşmediği gözlenmiştir. Gaz çıkışı görülen izolatlar katalaz-pozitif, gaz çıkışı görülmeyenler ise katalaz-negatif olarak değerlendirilmiştir.

\subsubsection{Gram Boyama}

$37^{\circ} \mathrm{C}^{\prime}$ de 24 saat geliştirilen her bir sıvı kültürden $20 \mu \mathrm{L}$ alınarak temiz bir lam üzerine basit damlatılmıştır. Kurutulan örnekler bek alevinden geçirilerek fiksasyon işlemi tamamlanmıştır. Kristal viyole solüsyonu damlatılarak 1 dakika muamele edilmiştir. Boya saf su ile yıkanarak uzaklaştırılmış ve preparat üzerine gram iyodin solüsyonu damlatılarak 1 dakika bekletilmiştir. Süre sonunda lamın üzerindeki gram iyodin saf su ile yıkanarak uzaklaştırılmıştır. Daha sonra 30 saniye boyunca dekolorizer (\%96' lik etil alkol) solüsyonu ile muamele edilmiştir. Ardından saf su ile yıkama işlemi gerçekleştirilmiştir. Safranin ile 30 saniye boyandıktan sonra örnekler yıkanarak boyası giderilmiştir. Kurutma kâğıdında veya havada kurutulan örneklerin üzerine immersiyon yağı damlatılarak ışık mikroskobu ile incelenmiştir. $\mathrm{Bu}$ yöntemle mavi-mor görünen mikroorganizmalar gram pozitif, pembe-kırmızımsı renkte görülenler ise gram negatif olarak değerlendirilmiştir.

\subsubsection{Genomik DNA izolasyonu}

MRS sivı besiyerinde $37^{\circ} \mathrm{C}$ ' de 24 saat geliștirilen aktif kültürler eppendorf tüplere $1000 \mu \mathrm{L}$ olacak şekilde dağıtılıp 13200 rpm de 1 dakika santrifüjlenmiştir. Süpernatant 
uzaklaştırılmış ve dipteki pelletin üzerine $1000 \mu \mathrm{L}$ aktif kültür eklenip tekrar santrifüj işlemi gerçekleştirilmiştir. Süpernatant uzaklaştırıldıktan sonra $200 \mu \mathrm{L}$ spheroblast buffer (\%10 sükroz, 2mg/ml lizozim, 0,4 mg/ml RNAse, $25 \mathrm{mM}$ Tris $\mathrm{pH}: 8.4,25 \mathrm{mM}$ EDTA pH:8) eklenmiş ve $37^{\circ} \mathrm{C}^{\prime}$ de 15 dakika bekletilmiştir. Süre sonunda önce $50 \mu \mathrm{L}$ lizis buffer-1 (\%5 SDS çözeltisi) eklenmiş ve ardından $50 \mu \mathrm{L}$ lizis buffer-2 (5 M NaCl çözeltisi) eklemiştir. Tüpler nazikçe karıştırılarak $65^{\circ} \mathrm{C}$ ' de 5 dakika sıcak su banyosunda bekletilmiştir. Daha sonra örneklerin üzerine $100 \mu \mathrm{L}$ $\mathrm{N} 3$ tamponu (5 M sodyum asetat $60 \mathrm{ml}$, asetik asit $11.5 \mathrm{ml}$, distile su 28.5) eklenip 5 dakika boyunca buz içinde bekletilmiştir. Tüpler süre bitiminde $+4^{\circ} \mathrm{C}^{\prime}$ de 15 dakika santrifüjlenmiştir. $\mathrm{Bu}$ işlem bittikten sonra örneklerdeki süpernatant kısmından $400 \mu \mathrm{L}$ alınıp steril ve yeni bir eppendorf tüpe aktarılmış ve üzerine 400 $\mu \mathrm{L}$ izopropanol eklenmiş ve oda sıcaklığında 15 dakika santrifüjlenmiştir. Süpernatant kısmı uzaklaştırıldıktan sonra pellet $100 \mu \mathrm{L} \% 96$ ' lik etanolle yıkanmıştır. Örnekler oda sıcaklığında 16000 rpm' de 5 dakika santrifüjlenmiştir. Süpernatant uzaklaştırıldıktan sonra pellet \%70' lik etil alkol ile yıkanmış ve vortekslenmiştir. Oda sıcaklığında 16000 rpm' de 5 dakika santrifüjlenip süpernatant tekrar uzaklaştırılmıştır. Pellet yarım saat boyunca etüvde kurumaya bırakılmıştır. Daha sonra üzerine $50 \mu \mathrm{L}$ steril DNAz RNAz içermeyen su eklenerek $-20^{\circ} \mathrm{C}$ ' de saklanmiştır.

\subsubsection{RAPD (Randomly Ampliffied Polimorphic DNAs) $P Z R$ profillerinin belirlenmesi}

RAPD-PZR işlemi için DNA' lar üzerinde farklı bölgelere bağlanıp farklı gen dizilimleri oluşmasına sebep olacak 8-10 nükleotit uzunluğundaki OPA-7 (5'GAAACGGGTG 3') ve OPA14 (5'TGCTGCAGGT 3') primerleri kullanılmıştır. PZR tüplerinin içerisine her bir örnek için son hacim $25 \mu \mathrm{L}$ olacak şekilde sırasıyla $8 \mu \mathrm{L}$ saf su, $0.5 \mu \mathrm{L}$ primer, $1 \mu \mathrm{L} \mathrm{MgCl}_{2}, 12.5 \mu \mathrm{L}$ master mix (BIO-RAD iProof High-Fidelity Master Mix) ve son olarak da $3 \mu \mathrm{L}$ kalıp DNA eklenmiştir. Tüpler PZR cihazına yerleştirilerek $94^{\circ} \mathrm{C}^{\prime}$ de 5 dakika ön denatürasyon işleminin ardından, $94^{\circ} \mathrm{C}^{\prime}$ de 1 dakika denatürasyon, $58^{\circ} \mathrm{C}^{\prime}$ de 1 dakika primer bağlanması ve $72^{\circ} \mathrm{C}^{\prime}$ de 1 dakika 45 saniye uzama basamaklarından oluşan 44 döngü içeren bir işlem gerçekleştirilmiştir. Programın sonuna $72^{\circ} \mathrm{C}$ ' de 10 dakika olacak şekilde ilave uzama basamağı ve $+4^{\circ} \mathrm{C}$ hold basamağ amplifikasyon işlemi gerçekleştirilmiştir.

\subsubsection{S rDNA dizi analizi}

Bakteri kültürlerinden izole edilen genomik DNA örneklerindeki 16S rDNA bölgelerini çoğaltmak amacıyla 27-F (5'-AGA GTT TGA TCC TGG CTC AG-3') ve 1492-R (5'-CTA CGG CTA CCT TGT TAC GA-3') primer çifti kullanılmıştır. PZR tüpüne her örnek için toplamda $25 \mu \mathrm{L}$ olacak şekilde sırasıyla $15,875 \mu \mathrm{L}$ saf su, $5 \mu \mathrm{L}$ Taq buffer, $1 \mu \mathrm{L}$ dNTP mix, $0.5 \mu \mathrm{L}$ F primer, $0.5 \mu \mathrm{L}$ R primer, $1 \mu \mathrm{L} \mathrm{MgCl}_{2}, 0.25 \mu \mathrm{L}$ Taq polimeraz ve $1 \mu \mathrm{L}$ kalıp DNA ilave edilmiştir. PZR tüpleri PZR cihazına yerleştirilerek, $94{ }^{\circ} \mathrm{C}^{\prime}$ de 1 dakika denatürasyon, $58^{\circ} \mathrm{C}^{\prime}$ de 10 saniye primer bağlanmas 1 ve $72^{\circ} \mathrm{C}^{\prime}$ de 1 dakika 45 saniye uzama basamaklarından oluşan toplam 35 döngüden oluşan uygulamaya ilaveten $72^{\circ} \mathrm{C}$ ' de 10 dakika ilave uzama basamağı işlemi gerçekleştirilmiştir (Osmanagaoglu ve ark., 2010). Örneklerin PZR dizi analizleri BM Labosis (Ankara, Türkiye) tarafından yapılmıştır. Dizi analiz sonuçları FinchTV programında açılmış ve FASTA formatına dönüştürülmüştür. FASTA formatındaki diziler NCBI veri tabanında BLAST programı kullanılarak tanımlanmış olan tüm sekanslarla karşılaştırılmış ve sekansın hangi mikroorganizma türüne ait olabileceği bilgisine ulaşılmıştır. e-ISSN: 2148-2683
Elde edilen diziler MEGA7 programında işlenerek contigler oluşturulmuş ve NCBI veri tabanında var olan referans diziler kullanılarak 16S rRNA dizi sonuçlarına göre karşılaştırmalı filogenetik ağaç oluşturulmuştur.

\subsubsection{Suşların bakteriyosin üretim özelliklerinin belirlenmesi}

$37^{\circ} \mathrm{C}$ ' de bir gece geliştirilmiş kültürlerden $2000 \mu \mathrm{L}$ alınıp steril mikrosantrifüj tüplere konulmuştur. Tüpler 12.000 rpm' de 10 dakika santrifüjlenmiştir. Santrifüj işleminden sonra mikropipetle süpernatanttan $1000 \mu \mathrm{L}$ çekilmiş, steril bir tüpe aktarılmış ve pH' si $5 \mathrm{M} \mathrm{NaOH}$ ile pH:7.0 olacak şekilde ayarlanmış ve $0.22 \mu \mathrm{m}$ çaplı filtrelerden geçirilmiştir. Filtre işleminin ardından örnekler $100^{\circ} \mathrm{C}$ ' de 5 dakika kaynatılmıştır. $\mathrm{Bu}$ deneyde kullanılan indikatör mikroorganizmalar Listeria monocytogenes NCTC 5348, Salmonella enterica TyphimiriumATCC 14028, Şiga toksin-üreten Escherichia coli O157:H7ATCC 35150 TSA besi ortamında ve laktik asit bakterileri Pediococcus acidilactici, Lactococcus lactis, Lactobacillus sakei ise MRS besi ortamında 1 gece $37^{\circ} \mathrm{C}$ ' de geliştirilmiştir. Bu mikroorganizmaların gelişimi için hazırlanan uygun katı besiyerleri petrilere dökülmüştür. Her mikroorganizma için ayrıca yarı katı besi ortamı ( $\% 0.75$ agar içeren) hazırlanmıştır. bir gece geliştirilen indikatör mikoorganizmalardan yarı katı besi ortamlarına $\% 1$ oranında aşılama yapılmıştır ve hazırlanan petrilerin üzerine dökülmüştür. 10 dakika katılaşması için beklenmiştir. Agar donduktan sonra steril cam borular yardımıyla yaklaşık $0.6 \mathrm{~cm}$ çapında kuyular açılmıştır. Kontrol olarak pediyosin üreticisi olan Pedioccoccus pentasaceous OZF suşu kullanılmıştır. Hazırlanmış olan süpernatantlardan $10 \mu \mathrm{L}$ olacak şekilde kuyulara yüklenme yapılmıştır. Sıvının besi ortamına diffüze olması için 30-60 dakika beklenip ve $37^{\circ} \mathrm{C}$ ' de 24 saat inkübasyona bırakılmıştır. İnkübasyon sonunda bakteriyosin zonlarının çapı $\mathrm{cm}$ cinsinden ölçülmüştür. Zon oluşumunun gözlendiği suşlar bakteriyosin pozitif olarak değerlendirilmiştir.

\subsubsection{Suşların antibiyotik duyarlılıklarının belirlenmesi}

Antibiyotik testi için disk diffüzyon ve minimum inhibisyon konsantrasyon (MIK) testleri uygulanmıştır. Öncelikle $37^{\circ} \mathrm{C}$ ' de 18 saat geliştirilmiş aktif kültürler seri dilüsyonlar halinde hazırlanarak $1 \times 10^{5} \mathrm{kob} / \mathrm{ml}$ olacak şekilde pepton içerisinde seyreltilmiştir. Seyreltilmiş suşlardan $1 \mathrm{ml}$ alınıp MRS agar bulunan petrilere toplam 3 paralel olacak şekilde yayılmıştır. Ardından 6 çeşit antibiyogram diskleri (eritromisin, vankomisin, tetrasiklin, kanamisin, gentamisin ve kloramfenikol) petriye uygun aralıklarla dizildikten sonra $37{ }^{\circ} \mathrm{C}$ ' de 18 saat inkübasyon için etüve kaldırılmıştır. Antibiyotik diskleri etrafındaki zon çapları mm olarak ölçülmüştür. MİK testinde ise hücre yoğunluğu $1 \times 10^{5} \mathrm{kob} / \mathrm{ml}$ olan suşlara farklı konsantrasyonlarda $(0.5,1,2,4$, $8,16,32,64,128,256,512,1024,2048 \mu \mathrm{g} / \mathrm{ml}$ ) antibiyotikler (vankomisin, amfisilin, penisilin-g ve streptomisin) eklenip $37^{\circ} \mathrm{C}$ ' de 18 saat inkübasyona bırakılmıştır. Gelişimin gözlenmediği minimum antibiyotik değeri MIK değeri olarak hesaplanmıştır (Kim ve ark., 2021; Sharma ve ark., 2017).

\subsubsection{Suşların düşük pH değerlerine karşı direnç özelliklerinin belirlenmesi}

$\mathrm{Bu}$ testte midenin asidik ortamına benzer bir $\mathrm{pH}$ ortamı oluşturulmuş ve suşların bu ortamdan geçerek bağırsaklara ulaşabilme yeteneği incelenmiştir. İzolatlar $37^{\circ} \mathrm{C}$ ' de 18 saat 
geliştirilmiş ve izolatlardan 1' er ml eppendorf tüplere alınıp 12000 rpm' de 5 dakika $+4^{\circ} \mathrm{C}^{\prime}$ de santrifüjlendikten sonra süpernatant uzaklaştırılmıştır. PBS (pH:7.4) tamponu ile çökelti yıkanmıştır. Ardından ikinci kez santrifüj yapılmış ve süpernatant uzaklaştırılıp PBS (pH:7.4) tamponu ile tekrar yıkanmıştır. pH direncinin belirlenmesi için kullanılacak olan PBS tamponu $5 \mathrm{M}$ $\mathrm{HCl}$ ile pH' ları 2.0 ve 3.0 olacak şekilde ayarlanmıştır. Her suşa ait pellet pH' sı ayarlanan tamponları içeren tüplere eklenmiş ve tüpler vortekslenmiştir. Kontrol olarak; pH değeri 7.4 olan PBS kullanılmıştır. Tüpler $37^{\circ} \mathrm{C}^{\prime}$ de inkübasyona bırakılmıştır. 0 , 1 ve 3. saatlerde tüplerden alınan numunelerin seri dilüsyonları sonra petrilerdeki koloniler sayılmıştır. Değerler log-kob/ml olarak hesaplanmıştır (Maragkoudakis ve ark., 2006).

\subsubsection{Suşların pepsin direnci testi}

Suşların canlılık özellikleri üzerinde pepsinin etkisini görebilmek amacıyla $3 \mathrm{mg} / \mathrm{ml}$ pepsin (Merck, Almanya) içeren pH:2 ve pH:3' e ayarlanmış olan PBS tamponu kullanılmıştır. Çalışmada kontrol grubu olarak pepsin içermeyen pH:7.4 PBS tamponu kullanılmıştır. Bir gün önceden aktifleştirilmiş olan kültürlerden 1' er ml alınıp 12000 devirde 5 dakika $+4^{\circ} \mathrm{C}$ ' de santrifüj edilerek süpernatant uzaklaştırılmıştır. Pellet PBS (pH:7.4) ile iki kez yıkandıktan sonra, pepsin içeren PBS tamponlarıyla çözülerek $37^{\circ} \mathrm{C}$ de 3 saat inkübasyona bırakılmıştır. $0,1,3$. saatlerde örnekler alınarak seri dilüsyonlara tabi tutulmuş ve 3 paralel halinde MRS katı besiyerine yayma ekimleri yapılmıştır. $37^{\circ} \mathrm{C}^{\prime}$ de 48 saat inkübasyona bırakıldıktan sonra petrilerdeki koloniler sayılmıştır. Değerler log-kob/ml olarak hesaplanmıştır (Maragkoudakis ve ark., 2006).

\subsubsection{Suşların pankreatin direnci testi}

Suşların canlılık özellikleri üzerinde pankreatinin etkisini görebilmek amaciyla $1 \mathrm{mg} / \mathrm{ml}$ pankreatin (Merck, Almanya) içeren pH: 8.0' a ayarlanmış PBS tamponları ile kontrol grubu olarak pankreatin içermeyen $\mathrm{pH}$ : 7.4 olan PBS tamponu kullanılmıştır. Bir gün önceden aktifleştirilmiş olan kültürlerden $1^{\prime}$ er ml alınıp 12000 devirde 5 dakika $+4^{\circ} \mathrm{C}$ ' de santrifüj edilerek süpernatant uzaklaştırılmıştır. Pellet PBS (pH:7.4) tamponu ile iki kez yıkandıktan sonra, hazırlanmış olan PBS tamponlarının içerisinde çözülerek $37^{\circ} \mathrm{C}$ de 4 saat inkübasyona bırakılmıştır. 0 , 1, 3. ve 4. saatlerde örnekler alınarak seri dilüsyonlara tabi tutulmuş ve 3 paralel halinde MRS katı besiyerine yayma ekimleri yapılmıştır. $37^{\circ} \mathrm{C}^{\prime}$ de 24 saat inkübasyona bırakıldıktan sonra petrilerdeki koloniler sayılmıştır. Değerler log-kob/ml olarak hesaplanmıştır (Maragkoudakis ve ark., 2006).

\subsubsection{Suşların safra tuzu direnci testi}

Suşların canlılık özellikleri üzerinde safra tuzunun etkisini görebilmek amacıyla $\% 0.3, \% 0.5$ ve $\% 0.1$ oranında safra tuzu içeren MRS sıvı besiyerleri, kontrol grubu olarak safra tuzu içermeyen MRS sıvı besiyeri kullanılmıştır. Bir gün önceden aktifleştirilmiş olan kültürlerden 1'er ml alınıp 12000 devirde 5 dakika $+4^{\circ} \mathrm{C}^{\prime}$ de santrifüj edilerek süpernatant uzaklaştırılmıştır. Pellet PBS (pH:7.4) tamponu ile iki kez yıkandıktan sonra hazırlanmış olan $\% 0.3, \% 0.5$ ve $\% 0.1$ oranında safra tuzu içeren MRS sıvı besiyerlerinin içerisinde çözülerek $37^{\circ} \mathrm{C}$ de 4 saat inkübasyona bırakılmıştır. 0, 1, 3. ve 4. saatlerde örnekler alınarak seri dilüsyonlara tabi tutulmuş ve 3 paralel halinde MRS katı besiyerine yayma ekimleri yapılmıştır. $37^{\circ} \mathrm{C}^{\prime}$ de 24 saat inkübasyona bırakıldıktan sonra petrilerdeki koloniler sayılmıştır. Değerler log-kob/ml olarak hesaplanmıştır (Maragkoudakis ve ark., 2006).

\subsubsection{Suşların hemolitik aktivite testi}

$37^{\circ} \mathrm{C}^{\prime}$ de 24 saat geliştirilen suşlar, \%5 koyun kanı içeren Colombia agara çizgi ekim yöntemi kullanılarak aktarılmıştır. Kontrol olarak S. aureus ve E. coli suşları kullanılmıştır. Petriler etüvde 24 saat inkübasyona bırakılmıştır. İnkübasyon süresi sonunda etrafında yeşil zon oluşturan koloniler $\alpha$-hemolitik, berrak zon oluşturanlar $\beta$-hemolitik, zon oluşturmayanlar ise $\gamma$ hemolitik aktiviteye sahip olarak değerlendirilmiştir (Maragkoudakis ve ark., 2006).

\subsubsection{5 İstatistiksel analizler}

İstatistiksel analizler için SPSS 24 programında $t$ test ve Anova testleri kullanılmıştır. Post hoc analizi için TUKEY testi kullanılmıştır. Tüm istatistiksel analizler için $\mathrm{p}<0.05$ anlamlı kabul edilmiştir.

\section{Araştırma Sonuçları ve Tartışma}

\section{1. İzole edilen suşların katalaz aktivitesi, gram boyama ve morfolojik yapıları}

Muş ilinden temin edilen farklı kaynaklardan (sucuk numunesinden 2 adet, inek peyniri numunesinden 5 adet, karışı sütler (koyun-keçi-inek) kullanılarak oluşturulmuş Muş kaşarı numunesinden 4 adet, sadece inek sütü kullanılarak üretilmiş Muş kaşarı numunesinden 2, manda peyniri numunesinden 1 adet olmak üzere) toplam 14 adet suş izole edilmiştir. Suşlara verilen numaralar, izolasyon kaynakları, katalaz aktivitesi, gram boyama ve morfolojik yapıları Tablo 1' de verilmiştir.

\subsection{Suşların RAPD PZR profilleri}

OPA7 ve OPA14 primerleri ve elde edilen genomik DNA' lar kullanılarak gerçekleştirilen RAPD-PZR sonucunda oluşan ürünler \%1' lik agaroz jelde yürütülmüştür. OPA14 primeri ile ayırt edici özellikte bantlar elde edilemediğinden izolatların RAPD profilleri OPA7 primerine göre değerlendirilmiştir. Suşların RAPD-PZR işlemi sonunda elde edilen bant profilleri kullanılarak PyElph 1.4 programı yardımı ile filogenetik ağaç çizilmiştir (Şekil 1). İzolatlar arasından farklı bant profili sergileyen 1, 3, 16, 36, 39, 40 ve 44 numaralı izolatlar seçilerek çalışmaya bu izolatlar ile devam edilmiştir. 
Tablo 1. Suşlara verilen numaralar, izolasyon kaynakları, katalaz aktivitesi, gram boyama ve morfolojik yapıları

\begin{tabular}{|c|c|c|c|c|}
\hline Suş No & İzolasyon Kaynă̆ı & Katalaz Aktivitesi & Gram Boyama & Morfoloji \\
\hline 1 & Sucuk & - & + & basil \\
\hline 2 & Sucuk & - & + & basil \\
\hline 3 & İnek peyniri & - & + & kok \\
\hline 4 & İnek peyniri & - & + & kok \\
\hline 5 & İnek peyniri & - & + & kok \\
\hline 6 & İnek peyniri & - & + & kok \\
\hline 7 & İnek peyniri & - & + & kok \\
\hline 16 & Manda peyniri & - & + & kok \\
\hline 36 & Muş kaşar1-karış1k & - & + & kok \\
\hline 37 & Muş kaşar1-karış1k & - & + & kok \\
\hline 38 & Muş kaşarı-karış1k & - & + & kok \\
\hline 39 & Muş kaşar1-karış1k & - & + & kok \\
\hline 40 & Muş kaşar1-inek & - & & kok \\
\hline 44 & Muş kaşarı-inek & & & + \\
\hline
\end{tabular}

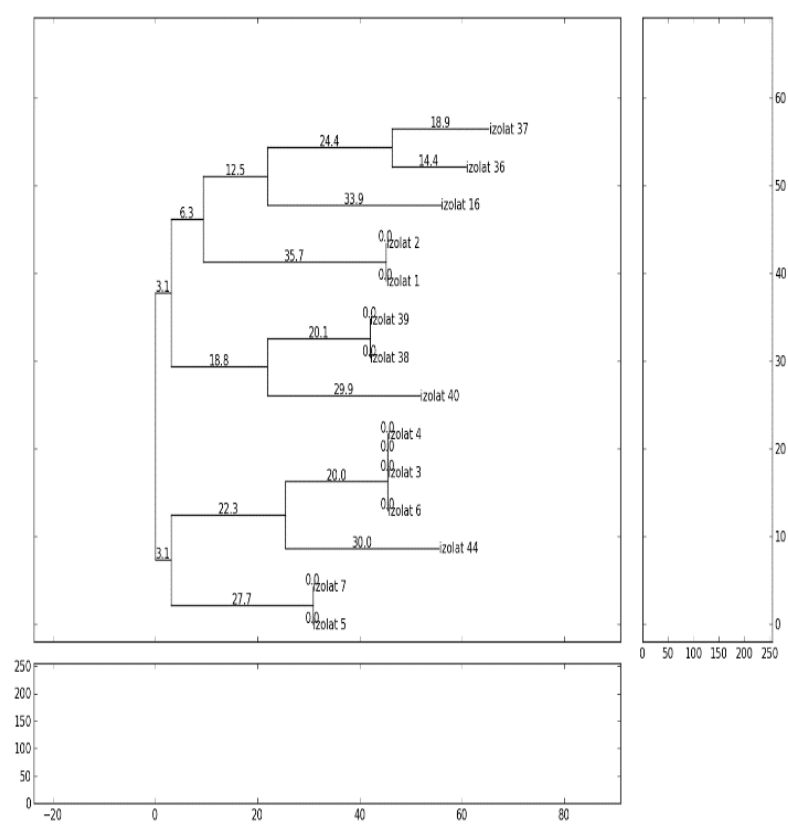

Şekil 1. Suşların RAPD bant profillerine göre oluşturulmuş filogenetik ăgaç görüntüsü

\subsection{S rDNA dizi analizi}

Suşların genotipik karakterizasyonunu belirlemek için toplam 7 adet izolattan elde edilmiş olan genomik DNA' lar 16S rDNA primerleri kullanılarak PZR işlemine tabi tutulmuştur. Oluşan ürünlerin agaroz jel elektroforezi kullanılarak jel görüntüleri elde edilmiştir (Şekil 2). Elde edilen PZR ürünleri BM Labosis (Ankara, Türkiye) firmasından hizmet alımı yapılarak dizilenmiş ve sonuçlar NCBI veri tabanındaki BLAST programında değerlendirilerek suşların moleküler tanımlaması gerçekleştirilmiştir. Elde edilen dizi sonuçları NCBI veri tabanındaki Genbank bölümüne kaydedilerek suşlar için NCBI aksesyon numaraları alınmıştır. Suşların moleküler tanımlama sonuçları ve alınan aksesyon numaraları Tablo 2' de verilmiştir. Dizileme sonuçları ve NCBI veri tabanındaki referans suşların dizileri MEGA7 programında işlenmiş ve evrimsel ilişkinin incelenmesi için izolatlara ait 16S rRNA gen dizileri ve NCBI veri tabanındaki referans suşlara ait $16 \mathrm{~S}$ rRNA gen dizileri ile Neighbor-Joining yöntemi kullanılarak filogenetik ağaç oluşturulmuştur (Saitou ve Nei, 1987). Ağaç üzerindeki dal e-ISSN: 2148-2683 uzunluklarının toplamı 1.029 olarak belirlenmiștir. Taksonomik kümelerle ilişkili olan ağaç üzerindeki dalların yüzdesi bootstrap yöntemi kullanılarak (1000 tekrar) belirlenmiştir (Felsenstein, 1985). Filogenetik ağacın oluşturulması için evrimsel mesafelerle aynı birimlere sahip olan dal uzunluk ölçekleri kullanılmıştır. Evrimsel mesafeler maksimum Kompozit Likelihood metodu kullanılarak hesaplanmıştır (Tamura ve ark., 2004). Analizler 20 nükleotit dizisini içermektedir. Dahil edilen kodon pozisyonları; birinci, ikinci ve üçüncü kodlanmayan bölgelerdir. Bütün pozisyonlardaki açıklıklar ve kayıp veriler elimine edilmiştir. Son işlenen veri seti içerisinde 757 pozisyon bulunmaktadır. Evrimsel analiz MEGA7 (Şekil 3) programı ile gerçekleştirilmiştir (Kumar ve ark., 2016).

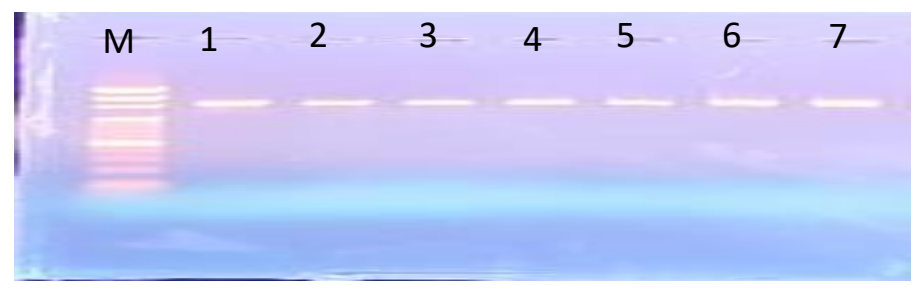

Şekil 2. PZR ile çoğaltılmış $16 S$ rDNA bölgelerinin jel görüntüsü (M: marker, 1: 1 numarall izolat, 2: 3 numarall izolat, 3: 16 numaral izolat, 4: 36 numaral izolat, 5: 39 numaral izolat, 6: 40 numarall izolat, 7: 44 numarall izolat).

Tablo 2. Suşların 16S rDNA dizi analizi sonucundaki suş adlart ve aksesyon numaralart

\begin{tabular}{cccc}
\hline $\begin{array}{c}\text { Suş } \\
\text { Kodu }\end{array}$ & $\begin{array}{c}\text { 16S rDNA Dizisine Göre } \\
\text { Yapılan Tanı }\end{array}$ & Suş Ad1 & $\begin{array}{c}\text { NCBI } \\
\text { Aksesyon } \\
\text { Numaralar1 }\end{array}$ \\
\hline 1 & Lactobacillus sakei & MH1 & MW633193 \\
3 & Lactococcus garvieae & MH2 & MW633194 \\
16 & Enterococcus faecium & MH5 & MW633197 \\
36 & Pediococcus acidilactici & MH10 & MW633202 \\
39 & Pediococcus acidilactici & MH11 & MW633203 \\
40 & Pediococcus acidilactici & MH12 & MW633204 \\
44 & Pediococcus acidilactici & MH13 & MW633205 \\
\hline
\end{tabular}

\subsection{Suşların antibiyotik duyarlılıkları}

EFSA' nın belirlemiş olduğu 6 antibiyotiğin (eritromisin $(15 \mu \mathrm{g})$, tetrasiklin $(30 \mu \mathrm{g})$, kanamisin $(30 \mu \mathrm{g})$, vankomisin $(30$ 
$\mu \mathrm{g})$, gentamisin $(10 \mu \mathrm{g})$ ve kloramfenikol $(30 \mu \mathrm{g}) 3$ paralel halinde yapılan disk diffüzyon testi sonucunda zon çapları $\mathrm{mm}$ olarak ölçülmüştür ve sonuçlar Tablo 4' te verilmiştir. Sonuçlar Clinical and Laboratory Standards Institute (CLSI, 2015) yönergeleri tarafından önerilen break-point'e göre şu şekilde yorumlanmıştır: 14 mm' den küçük veya eşit inhibisyon bölgesine sahip izolatlar dirençli (R), 20 mm' den fazla çapa sahip olanlar duyarlı (S) ve zon çapı 15 ila $19 \mathrm{~mm}$ arasında olanlar orta duyarlı (I) olarak kabul edilmiştir (Kim ve ark., 2021a; Sharma ve ark., 2017). Sonuçlara göre tüm suşlarda en çok direnç kanamisine karşı tespit edilirken, suşların eritromisin ve kloroamfenikole orta derece dirençli olduğu tespit edilmiştir.

Suşların antibiyotik direnç profilleri ayrıca MIKK testi kullanılarak da belirlenmiştir. MİK testi için vankomisin, amfisilin, penisilin-G ve streptomisin antibiyotikleri kullanılmış ve elde edilen sonuçlar Tablo 5' te verilmiştir. MÍK test sonuçlarının değerlendirilmesi için Avrupa Antimikrobik Duyarlılık Testleri Komitesi (EUCAST, 2019) referans alınmıştır. Laktobasil grubu genellikle kloramfenikol, eritromisin, klindamisin ve tetrasiklin gibi proteinlerin sentezini inhibe eden antibiyotiklere duyarlıdır ve aminoglikozitlere (neomisin, kanamisin, streptomisin ve gentamisin) karşı daha dirençlidir (Ammor ve ark., 2007; Charteris ve ark., 1998; Coppola ve ark., 2005; Zhou ve ark., 2005).

\subsection{Suşların bakteriyosin üretim özellikleri}

Örneklerden izole edilen suşların bakteriyosin üretiminin belirlenmesi için yapılan testin sonucunda suşların incelenen indikatör mikroorganizmalara karşı zon oluşturmadığı tespit edilmiştir.

\subsection{Suşların pH direncinin belirlenmesi}

Bir suşun probiyotik sınıfına dahil edilmesi için mide asidine dayanıklı olması gerekmektedir. Midede kalma süresi yaklaşık 3 saat olduğu için, 3 saat süreyle düşük $\mathrm{pH}$ düzeylerinde suşların pH dirençlilik testleri gerçekleştirilmiştir (Dunne ve ark., 2001; Vinderola ve Reinheimer, 2003) ve test sonuçları Şekil 4 ve Şekil 5' te verilmiştir. Yapılan $\mathrm{pH}$ denemeleri sonucunda $\mathrm{pH}: 2$ birinci saat sonunda 1,3 ve 36 numaralı izolatların canlılığını koruduğu buna karşın 3 . saat sonunda tüm suşların canlılığını kaybettiği tespit edilmiştir. pH: 3 testlerinde ise 3 . saat sonunda tüm suşların canlılığını koruduğu en az canlılık gösteren suşun 1 numaralı izolat olduğu en fazla canlılık oranının ise 3 ve 36 numaralı izolatlarda görüldüğü tespit edilmiştir. Probiyotik bakterilerin düşük $\mathrm{pH}$ ve safra tuzlarına karşı direnci büyük ölçüde türe bağlıdır (Muñoz-Quezada ve ark., 2013). Bazı laktik bakterilerin asidik $\mathrm{pH}$ tolerans1, bu mikroorganizma grubunda bulunabilen bir enzim olan ATPaz' in varlı̆̆ ile ilgilidir (Lertworapreecha ve ark., 2011; Reis ve ark., 2016).

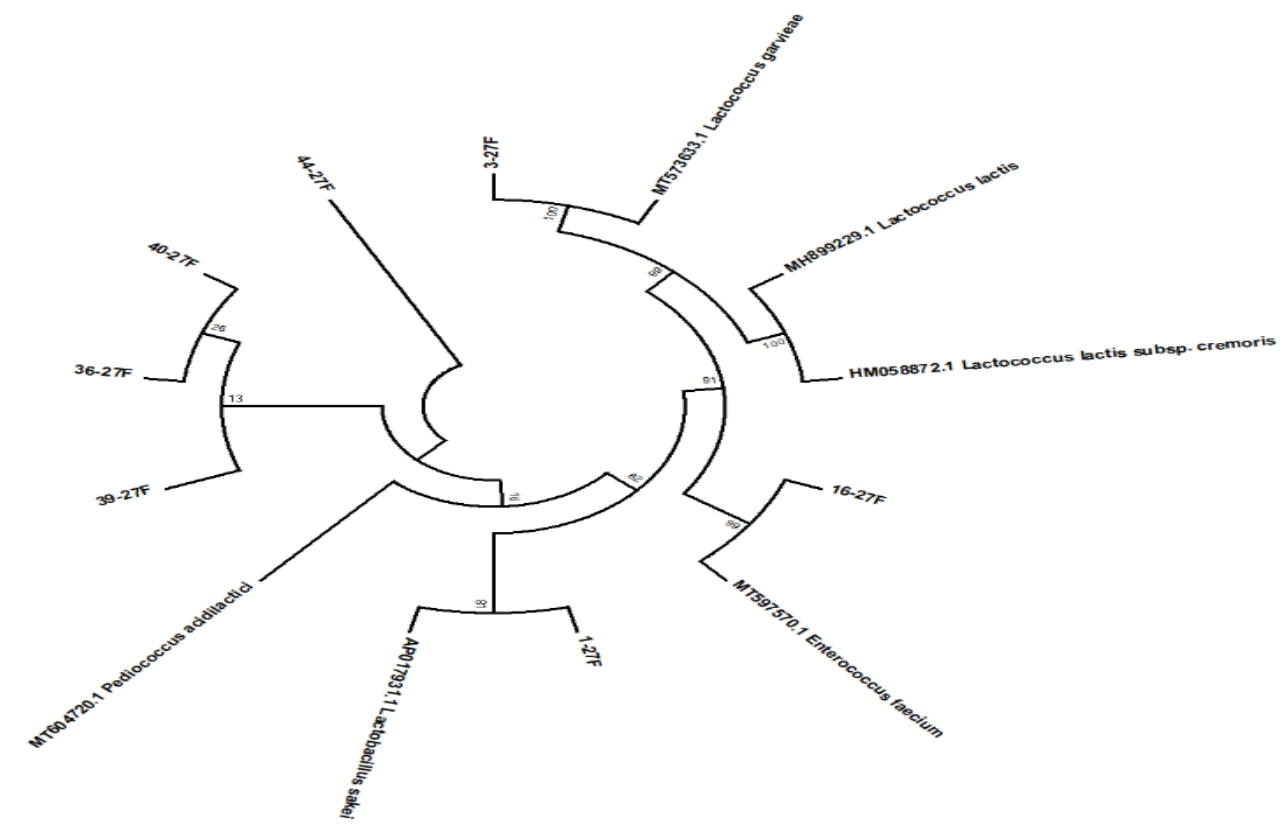

Şekil 3. Suşların $16 S$ rRNA gen dizileri ve NCBI veri tabanındaki referans suşlara ait $16 S$ rRNA gen dizilerine göre filogenetik ağaç görüntüsü.

Tablo 4. Suşların antibiyotik duyarlılık testi zon çapları ( $R \mathrm{~mm})$

\begin{tabular}{ccccccc}
\hline $\begin{array}{l}\text { SuŞ } \\
\text { Kodu }\end{array}$ & Eritromisin & Tetrasiklin & Kanamisin & Vankomisin & Gentamisin & Kloramfenikol \\
\hline 1 & $15 \mu \mathrm{g}$ & $30 \mu \mathrm{g}$ & $30 \mu \mathrm{g}$ & $30 \mu \mathrm{g}$ & $10 \mu \mathrm{g}$ & $30 \mu \mathrm{g}$ \\
\hline & $21,5 \pm 1,0-\mathbf{S}$ & $9,5 \pm 1,0-\mathbf{R}$ & $7,0 \pm 1,0-\mathbf{R}$ & $3,5 \pm 1,0-\mathbf{R}$ & $9,5 \pm 1,0-\mathbf{R}$ & $15,5 \pm 1,0-\mathbf{I}$ \\
16 & $22,0 \pm 1,0-\mathbf{S}$ & $18 \pm 1,0-\mathbf{I}$ & $11,0 \pm 1,0-\mathbf{R}$ & $19,5 \pm 1,0-\mathbf{I}$ & $11,0 \pm 1,0-\mathbf{R}$ & $23,5 \pm 1,0-\mathbf{S}$ \\
36 & $12,0 \pm 1,0-\mathbf{R}$ & $9,0 \pm 1,0-\mathbf{R}$ & $9,5 \pm 1,0-\mathbf{R}$ & $16,0 \pm 1,0-\mathbf{I}$ & $7,5 \pm 1,0-\mathbf{R}$ & $17,0 \pm 1,0-\mathbf{I}$ \\
39 & $18,5 \pm 1,0-\mathbf{I}$ & $14,0 \pm 1,0-\mathbf{R}$ & - & - & $3,5 \pm 1,0-\mathbf{R}$ & $21,0 \pm 1,0-\mathbf{S}$ \\
40 & $23,0 \pm 1,0-\mathbf{S}$ & $7,5 \pm 1,0-\mathbf{R}$ & - & - & - & $22,0 \pm 1,0-\mathbf{S}$ \\
44 & $18,0 \pm 1,0-\mathbf{I}$ & $7,0 \pm 1,0-\mathbf{R}$ & $3,5 \pm 1,0-\mathbf{R}$ & - & $4,5 \pm 1,0-\mathbf{R}$ & $13,0 \pm 1,0-\mathbf{R}$ \\
\hline
\end{tabular}

"-" Zon görülmemiştir. Susceptible: >20 (mm), Intermidiate: 15-19 (mm), Resistance: $\leq 14$ (mm) 
Tablo 5. Suşların MiK testi değerleri $(\mu \mathrm{g} / \mathrm{ml})$ ve dirençleri

\begin{tabular}{ccccc}
\hline Suş Kodu & Vankomisin & Amfisilin & Penisilin-G & Streptomisin \\
\hline 1 & $\mathrm{R}$ & $\mathrm{S}$ & $\mathrm{I}$ & $\mathrm{R}$ \\
& $1024 \mu \mathrm{g} / \mathrm{ml}$ & $2 \mu \mathrm{g} / \mathrm{ml}-\mathrm{S}$ & $<0,5 \mu \mathrm{g} / \mathrm{ml}$ & $16 \mu \mathrm{g} / \mathrm{ml}$ \\
3 & $\mathrm{~S}$ & $\mathrm{~S}$ & $\mathrm{R}$ & $\mathrm{R}$ \\
& $<0,5 \mu \mathrm{g} / \mathrm{ml}$ & $<0,5 \mu \mathrm{g} / \mathrm{ml}$ & $16 \mu \mathrm{g} / \mathrm{ml}$ & $64 \mu \mathrm{g} / \mathrm{ml}$ \\
16 & $\mathrm{R}$ & $\mathrm{I}$ & $\mathrm{R}$ & Yüksek düzey dirençli \\
& $512 \mu \mathrm{g} / \mathrm{ml}$ & $16 \mu \mathrm{g} / \mathrm{ml}$ & $4 \mu \mathrm{g} / \mathrm{ml}$ & $>2048 \mu \mathrm{g} / \mathrm{ml}$ \\
36 & $\mathrm{R}$ & $\mathrm{R}$ & $\mathrm{R}$ & $\mathrm{R}$ \\
& $512 \mu \mathrm{g} / \mathrm{ml}$ & $1024 \mu \mathrm{g} / \mathrm{ml}$ & $1 \mu \mathrm{g} / \mathrm{ml}$ & $64 \mu \mathrm{g} / \mathrm{ml}$ \\
39 & $\mathrm{R}$ & $\mathrm{R}$ & $\mathrm{I}$ & $\mathrm{R}$ \\
& $1024 \mu \mathrm{g} / \mathrm{ml}$ & $2048 \mu \mathrm{g} / \mathrm{ml}$ & $<0,5 \mu \mathrm{g} / \mathrm{ml}$ & $32 \mu \mathrm{g} / \mathrm{ml}$ \\
40 & $\mathrm{R}$ & $\mathrm{R}$ & $\mathrm{I}$ & $\mathrm{R}$ \\
& $1024 \mu \mathrm{g} / \mathrm{ml}$ & $2048 \mu \mathrm{g} / \mathrm{ml}$ & $<0,5 \mu \mathrm{g} / \mathrm{ml}$ & $128 \mu \mathrm{g} / \mathrm{ml}$ \\
44 & $\mathrm{R}$ & $\mathrm{I}$ & $\mathrm{R}$ & $\mathrm{R}$ \\
& $2048 \mu \mathrm{g} / \mathrm{ml}$ & $8 \mu \mathrm{g} / \mathrm{ml}$ & $4 \mu \mathrm{g} / \mathrm{ml}$ & $128 \mu \mathrm{g} / \mathrm{ml}$ \\
\hline
\end{tabular}

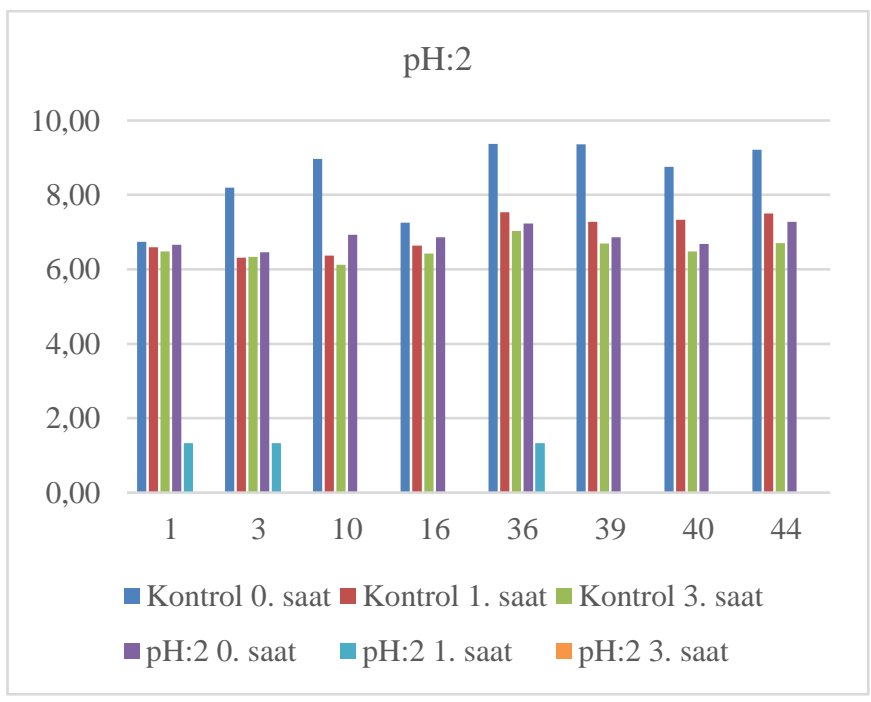

Şekil 4. İole edilen suşların pH:2 ve kontrol grubu sonuçları (log kob/ml)

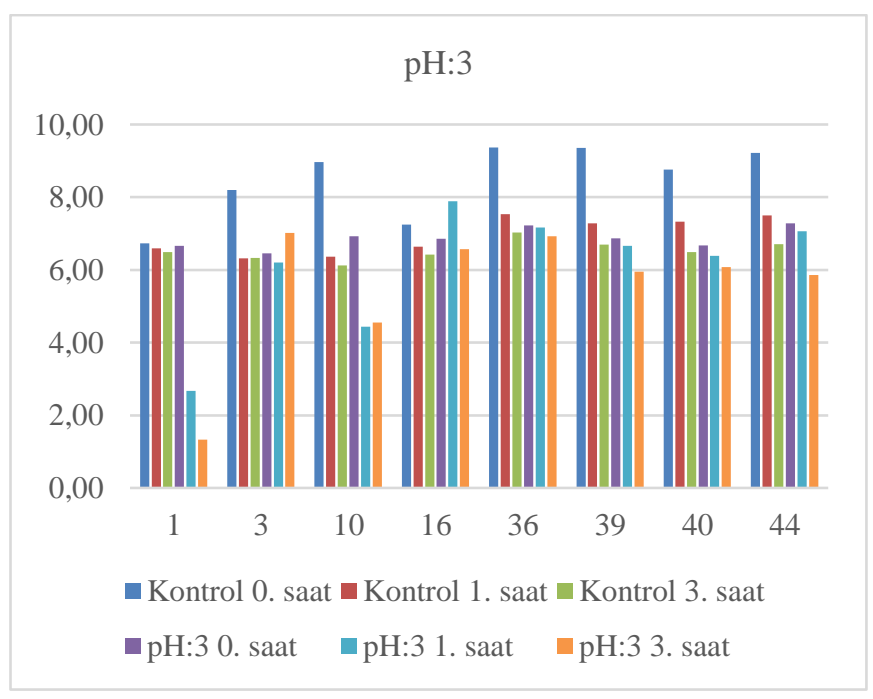

Şekil 5. İzole edilen suşların pH:3 ve kontrol grubu sonuçları $(\log \mathrm{kob} / \mathrm{ml})$

\subsection{Suşların safra tuzu direncinin belirlenmesi}

Sindirim sisteminden geçiş sırasında karşılaşılan koşullar altında mikroorganizmaların hayatta kalmaları probiyotikler için istenen özellikler arasındadır. Midede probiyotikler düşük pH' a, tuzlara, pepsin ve lizozim gibi enzimlere maruz kalmaktadırlar. $\mathrm{Bu}$ enzimlerin etkileri, probiyotikler de dahil olmak üzere organizmaların hayatta kalmasını etkilemektedir (Horáčková ve ark., 2012; Vizoso Pinto ve ark., 2006). Safra tuzuna karş1 direncin belirlenmesi için yapılan testler sonucunda tüm suşların safra tuzlarına karşı canlılıklarını koruduğu görülmüştür (Şekil 68). Kontrolle kiyaslandığında 4. saatin sonunda $\% 0,3$ ve $\% 0,5$ safra tuzu konsantrasyonunda en yüksek canlılık oranı 36 numaralı izolatta, en düşük canlılık oranı ise 1 numaralı izolatta belirlenmiştir. \%1 safra tuzu konsantrasyonunda ise 4 . saatin 
sonunda en yüksek canlılık oranı 39 numaralı izolatta görülmüştür.

\subsection{Suşların pankreatin direncinin belirlenmesi}

Pankreatin uygulamasının 4. saatin sonunda suşlardaki canlılık seviyesi deney grubu ve kontrol grupları için ortalama $\sim 7$ log düzeyinde gözlemlenmiştir. Sonuçlara ait veriler Şekil 9' da verilmiştir. Yapılan birçok çalışmada incelenen suşların $\mathrm{pH} 8^{\prime}$ de pankreatin maruziyetine karşı hayatta kaldığı ve canlılık oranlarının \%86 ile \%99 arasında değiştiği bildirilmiştir (El Jeni ve ark., 2016; Osmanagaoglu ve ark., 2010; Bove ve ark., 2012; Turchi ve ark., 2013; Xia ve ark., 2021). Birçok farklı çalışmada da insanlardan ve fermente gidalardan izole edilen laktobasil ve pediokok suşlarının pankreatin ve gastro intestinal sıvı içeren ortamlara dirençli olduğu ve canlılıklarını sürdürebildikleri belirtilmiştir (Bove ve ark., 2012; Turchi ve ark., 2013; Xia ve ark., 2021)

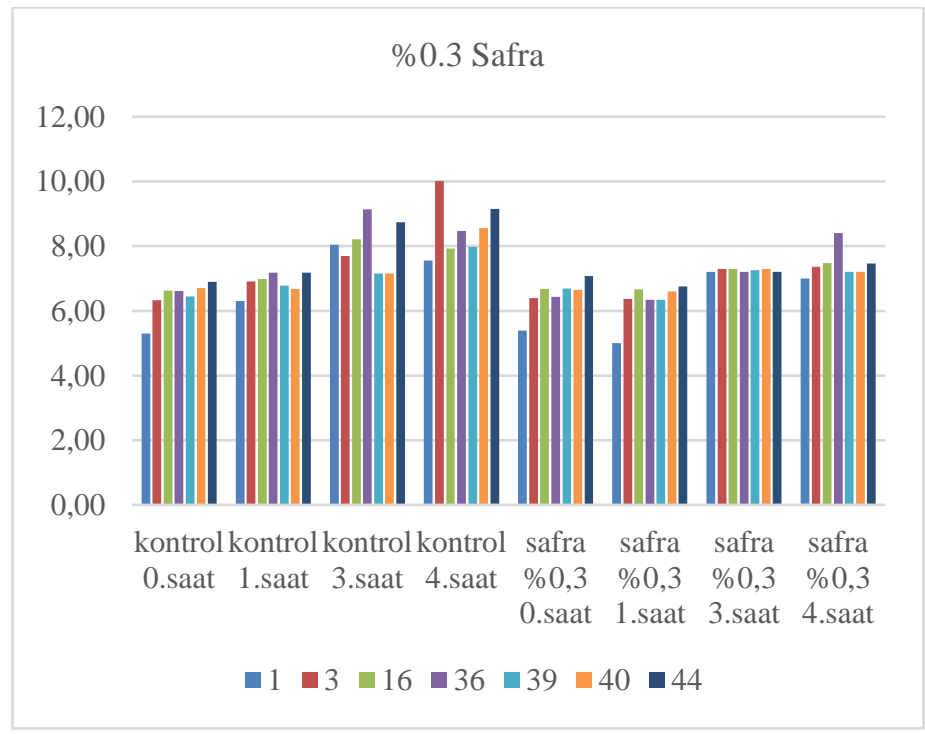

Şekil 6. Çalışmada kullanılan suşların \%0,3 safra tuzu sonuçları (log kob/ml)

\subsection{Suşların pepsin direncinin belirlenmesi}

Kontrol olarak çalışılan $\mathrm{pH} 7.4^{\prime}$ te 3 . saatin sonunda tüm suşlarda canlılık oranının yaklaşık 7-8 log arasında olduğu belirlenmiştir. Pepsin içeren $\mathrm{pH} 2.0$ tamponunda 1. saatin sonunda 1 numaralı suşun canlılık seviyesi $6.5 \log$ düzeyinde iken diğer suşlarda canlılık gözlenmemiştir. 3. saatin sonunda ise hiçbir suşta canlılık tespit edilmemiştir. Pepsin içeren pH 3.0 tamponunda 1. saatin sonunda 1 ve 44 numaralı suşların canlılığ iken; 3, 16, 36 ve 40 numaralı suşların ortalama $7.5 \log$;

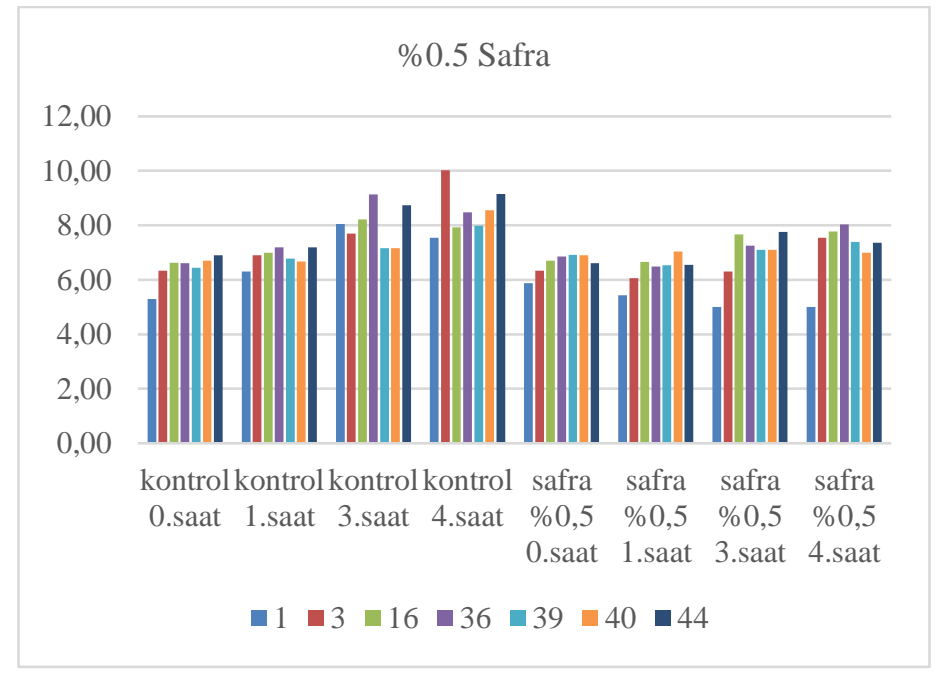

Şekil 7. Çalışmada kullanılan suşların \%0,5 safra tuzu sonuçları (log kob/ml)

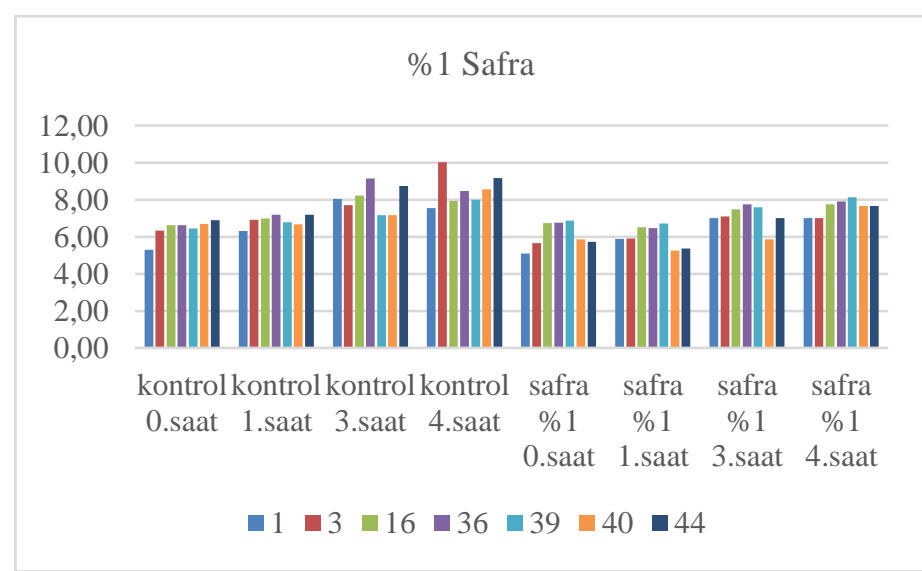

Şekil 8. Çalışmada kullanılan suşların \%1 safra tuzu sonuçları (log kob/ml)

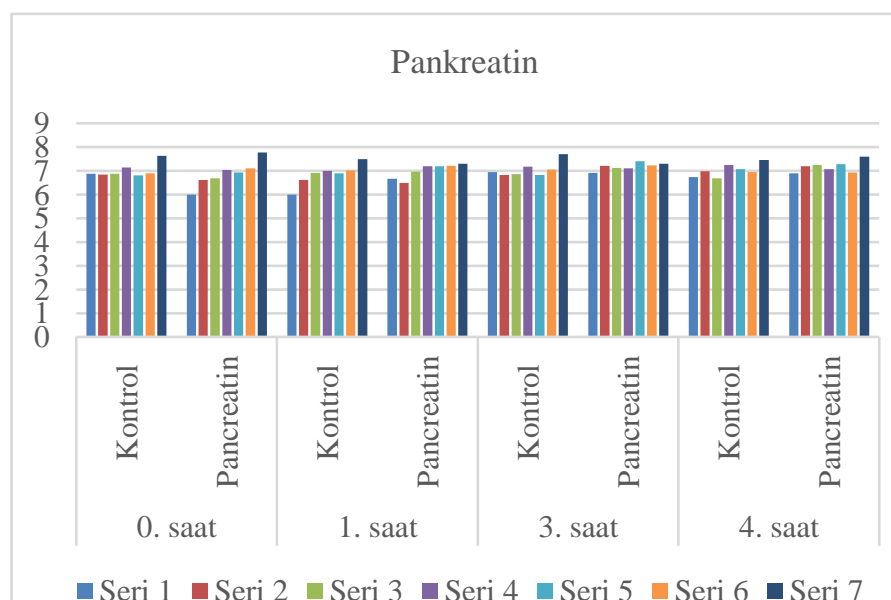

Şekil 9. Çalışmada kullanılan suşların pankreatin direnç profilleri $(\log \mathrm{kob} / \mathrm{ml})$

39 numaralı suşun $\sim 8$ log olarak belirlenmiştir.3. saatin sonunda ise tüm suşların canlılığını kaybettiği belirlenmiştir. Çalışmada kullanılan suşların pepsin direnç profilleri Şekil 10 ve Şekil 11' de verilmiştir. Liu ve ark., (2020) yaklardan izole ettikleri Lactobacillus sakei, Enterococcus hirae, Pediococcus acidilactici, Weissella confusa suşlarının probiyotik potansiyeli ve güvenlik değerlendirmelerini araştırdıkları çalışmalarında bu 
dört suşun temel olarak pepsin içeren $\mathrm{pH} 2.0$ tamponuna toleranslı olduğunu ve Pediococcus acidilactici suşunun pepsin ile aynı ortamda büyüyebileceğini bildirmiştir (Liu ve ark., 2020).

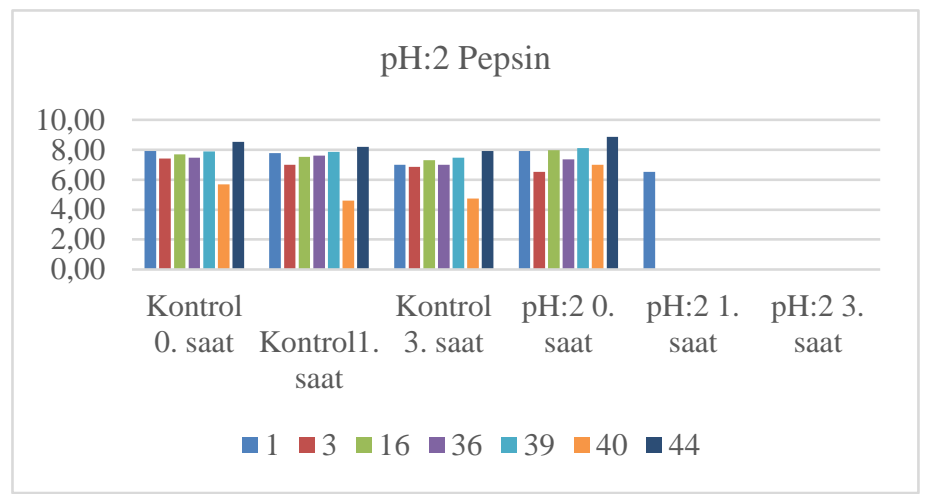

Şekil 10. Çalışmada kullanılan suşların pepsin (pH:2) direnç profilleri $(\log \mathrm{kob} / \mathrm{ml})$

\section{pepsin $\mathrm{pH}: 3$}

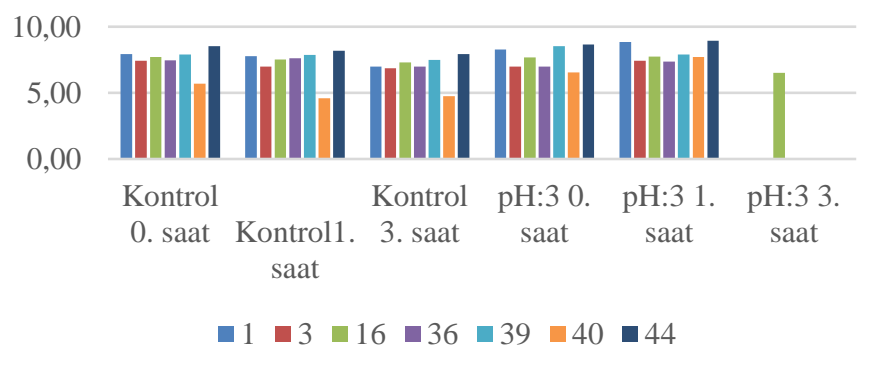

Şekil 11. Çalışmada kullanılan suşların pepsin (pH:3) direnç profilleri $(\log \mathrm{kob} / \mathrm{ml})$

\subsection{Suşların hemolitik aktiviteleri}

Hayvan model sistemleri ve insan enfeksiyonları üzerine yapılan çalışmalar hemolisin üretiminin enfeksiyon şiddetini arttırdığını göstermiştir, bu sebeple probiyotik olarak kullanılacak suşlarda hemolitik aktivite varlığı sorun oluşturmaktadır (Giridhara Upadhyaya ve ark., 2009; Koch ve ark., 2004; Morandi ve ark., 2006; Mundy ve ark., 2000; Yoğurtçu, 2011). Yapılan hemolitik aktivite testi sonucunda petrilerde zon oluşumu gözlenmemiş olduğundan tüm suşlar $\gamma$-hemolitik olarak değerlendirilmiştir. Hemolitik aktivite testi sonucundaki bazı örneklerdeki petri görüntüleri Şekil 12' de belirtilmiştir.

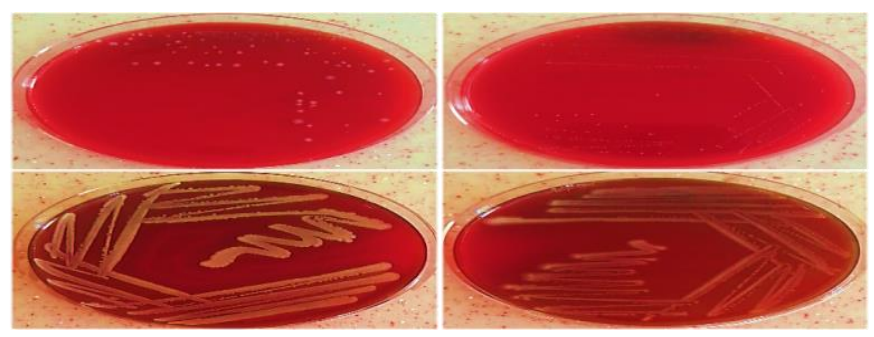

Şekil 12. Hemolitik aktivite testi sonucundaki bazı örneklerdeki petri görüntüleri (A: 1 numaralı izolat = Lactococcus lactis, $B: 40$ numarall izolat $=$ Pediococcus acidilactici, C: Staphylococcus aureus ATCC 25923, D: Escherichia coli ATCC 25922)

\section{Sonuç}

$\mathrm{Bu}$ çalışmada endüstri ve sağlık gibi alanlarda birçok öneme sahip laktik asit bakterileri farklı kaynaklardan (fermente gıda ürünleri) izole edilerek tanımlanmıştır. Suş düzeyinde tanımlanmış bu bakterilerin bazı probiyotik özellikleri araştırılmıştır.

Disk diffüzyon testi sonucuna göre kullanılmış olan eritromisin, tetrasiklin, kanamisin, vankomisin, gentamisin ve kloramfenikol antibiyotikleri arasından tüm suşlarda en çok direncin kanamisin antibiyotiğine, en az direncin ise eritromisin antibiyotiğine karşı olduğu tespit edilmiştir. Disk diffüzyon testi sonuçları verilmiştir. MİK testi sonuçlarına göre tüm suşların dirençli olduğu antibiyotiğin streptomisin, en az direnç gösterilen antibiyotiğin ise amfisilin olduğu gözlenmiştir. Suşların pepsine maruz bırakıldığı ortamdaki canlılıkları araştırıldığında en fazla canlılık pH:3.0 tamponunda 1. saatin sonunda görülmüş olup en yüksek canlılığın Muş kaşarı-karışık (inek, koyun, keçi sütlerinden)' dan izole 44 numaralı Pediococcus acidilactici MH13 suşunda olduğu tespit edilmiştir. pH:2.0 tamponundaki pepsin uygulamasında 3 . saatin bitiminde canlılık sifir olarak ölçülmüştür. Pankreatin uygulamasında 4. saatin sonunda tüm suşlarda canlılık görülmüş olup en yüksek canlılığın 44 numaralı Pediococcus acidilactici MH13 suşunda olduğu belirlenmiştir. Pankreatinin uygulandığ 1 tüm saatler arasında en yüksek canlılık oranının 3. saatin sonunda olduğu gözlenmiştir. $\% 0.3, \% 0.5$ ve $\% 1$ olarak uygulanmış safra tuzu ortamlarının tüm saatlerinde suşlar canlı olarak tespit edilmiştir. En yüksek canlılık oranı \%0.3' lük safra ortamında ölçülmüş olup en yüksek canlılık gösteren suş 36 numaralı Pediococcus acidilactici MH10 olarak belirlenmiştir. Bakteriyosin testinin sonucunda suşların incelenen indikatör mikroorganizmalara karşı bakteriyosin üretimi tespit edilememiştir. Bakteriyosinler, duyarlı hücreler üzerinde bakterisidal veya bakteriyostatik etki gösterebilir. Etkinin sidal veya statik olması, bakteriyosinin dozu ve saflık derecesi, indikatör hücrelerin fizyolojik durumu (büyüme fazı) ve sıcaklık, $\mathrm{pH}$, diğer antimikrobiyal bileşiklerin varlığı gibi çeşitli faktörlerden büyük ölçüde etkilenmektedir (Yang ve ark., 2014). Yapılan hemolitik aktivite testi sonucunda hiçbir petride zon oluşumu gözlenmemiş olduğundan tüm suşlar $\gamma$-hemolitik olarak değerlendirilmiştir.

Yapılan testler sonucunda izole edilen suşların in vitro olarak istenen özelliklerin çoğuna sahip olduğu ve mevcut potansiyel probiyotik adayları olduğu tespit edilmiş olmakla birlikte, diğer probiyotik seçim kriterlerine göre suşların test edilmesi gerektiği düşünülmektedir. Bu çalışmada probiyotik özellikleri araştırılmak üzere yapılan in-vitro analizler ile suşların probiyotik sınıfına dahil edilmesi için önemli veriler elde edilmiş olmasına rağmen, probiyotik seçim kriterlerinin tümü için suşların taranması önerilmektedir. Çalışmamızda izole ettiğimiz Lactococcus garvieae $\mathrm{MH} 2$ suşunun yapılan literatür taramasında probiyotik özellik gösteren türleri olduğu gibi patojen olan türlerinin de varlığ 1 tespit edilmiştir. Bu suşun ayrıntılı olarak çalışılması ve patojenite özelliği taşıyıp taşımadığının araştırılması önerilmektedir.

\section{Teșekkür}

$\mathrm{Bu}$ çalışma Muş Alparslan Üniversitesi Fen Bilimleri Enstiütüsü'nde yapılan yüksek lisans tezinden türetilmiştir. Çalışmaya vermiş olduğu proje desteğinden dolayı Muş Alparslan 
Üniveristesi Bilimsel Araştırma Projeleri Koordinatörlüğü birimine teşekkür ederiz (Proje no: BAP-20-TBMY-4902-04).

\section{Kaynakça}

Agheyisi, R. 2008. The probiotics market: Ingredients, supplements, foods, Report code: FOD035B, BCC Research, Wellesley, MA, USA.

Ammor, M.S., Belén Flórez, A. and Mayo, B. 2007. Antibiotic resistance in non-enterococcal lactic acid bacteria and bifidobacteria, Food Microbiology, 24 (6), 559-570.

Bintsis, T. 2018. Lactic acid bacteria as starter cultures: An update in their metabolism and genetics, AIMS Microbiology, 4 (4), 665-684.

Bove, P., Gallone, A., Russo, P., Capozzi, V., Albenzio, M., Spano, G. and Fiocco, D. 2012. Probiotic features of Lactobacillus plantarum mutant strains, Applied Microbiology and Biotechnology, 96 (2), 431-41.

Charteris, W.P., Kelly, P.M., Morelli, L. and Collins, J.K. 1998. Antibiotic susceptibility of potentially probiotic Lactobacillus species, Journal of Food Protection, 61 (12), 1636-43.

Coppola, R., Succi, M., Tremonte, P., Reale, A., Salzano, G. and Sorrentino, E. 2005. Antibiotic susceptibility of Lactobacillus rhamnosus strains isolated from Parmigiano Reggiano cheese, Le Lait, 85 (3), 193-204.

de Melo Pereira, G.V., de Oliveira Coelho, B., Magalhaes Junior, A.I., Thomaz-Soccol, V. and Soccol, C.R. 2018. How to select a probiotic? A review and update of methods and criteria, Biotechnology Advances, 36 (8), 2060-2076.

Diosma, G., Romanin, D.E., Rey-Burusco, M.F., Londero, A. and Garrote, G.L. 2014. Yeasts from kefir grains: isolation, identification, and probiotic characterization, World Journal of Microbiology and Biotechnology, 30 (1), 43-53.

Dunne, C., O'Mahony, L., Murphy, L., Thornton, G., Morrissey, D., O'Halloran, S., Feeney, M., Flynn, S., Fitzgerald, G., Daly, C., Kiely, B., O'Sullivan, G.C., Shanahan, F. and Collins, J.K. 2001. In vitro selection criteria for probiotic bacteria of human origin: correlation with in vivo findings, The American Journal of Clinical Nutrition, 73 (2), 386-392.

El-Jeni, R., El Bour, M., Calo-Mata, P., Böhme, K., FernándezNo, I.C., Barros-Velázquez, J. and Bouhaouala-Zahar, B. 2016. In vitro probiotic profiling of novel Enterococcus faecium and Leuconostoc mesenteroides from Tunisian freshwater fishes, Canadian Journal of Microbiology, 62 (1), 60-71.

EUCAST. 2019. The European Committee on Antimicrobial Susceptibility Testing. Breakpoint tables for interpretation of MICs and zone diameters. Version 9.0. http://www.eucast.org (Erişim Tarihi: 21 Haziran 2021).

FAO and WHO. 2002. Guidelines for the evaluation of probiotics in food. https://www.who.int/foodsafety/fs_management/en/probiotic _guidelines.pdf (Erişim Tarihi: 20 Haziran 2021).

Felsenstein, J. 1985. Confidence Limits on Phylogenies: An Approach Using the Bootstrap, Evolution, 39 (4), 783-791.

Fleet, G. and Balia, R. 2006. The public health and probiotic significance of yeasts in foods and beverages. in: Yeasts in food and beverages, Springer, 381-397.

Giridhara Upadhyaya, P.M., Ravikumar, K.L. and Umapathy, B.L. 2009. Review of virulence factors of Enterococcus: an emerging nosocomial pathogen, Indian Journal of Medical Microbiology, 27 (4), 301-5.

Horáčková, Š., Žaludová, K. and Plocková, M. 2012. Stability of selected lactobacilli in the conditions simulating those in the gastrointestinal tract, Czech Journal of Food Sciences, 29, 3035.

Jensen, H., Grimmer, S., Naterstad, K. and Axelsson, L. 2012. In vitro testing of commercial and potential probiotic lactic acid bacteria, International Journal of Food Microbiology, 153 (1), 216-222.

Kim, H., Shin, M., Ryu, S., Yun, B., Oh, S., Park, D.-J. and Kim, Y. 2021. Evaluation of probiotic characteristics of newly isolated lactic acid bacteria from dry-aged hanwoo beef, Food Science of Animal Resources, 41 (3), 468-480.

Koch, S., Hufnagel, M., Theilacker, C. and Huebner, J. 2004. Enterococcal infections: host response, therapeutic, and prophylactic possibilities, Vaccine, 22 (7), 822-830.

Kumar, S., Stecher, G. and Tamura, K. 2016. MEGA7: Molecular Evolutionary Genetics Analysis Version 7.0 for Bigger Datasets, Molecular Biology and Evolution, 33 (7), 1870-4.

Lertworapreecha, N., Poonsuk, K. and Chalermchiakit, T. 2011. Selection of potential Enterococcus faecium isolated from Thai native chicken for probiotic use according to the in vitro properties, Songklanakarin Journal of Science \& Technology, 33 (1).

Liong, M.T., Lee, B.H., Choi, S.B., Lew, L.C., Lau, A.S.Y. and Daliri, B.M.E., 2015. Cholesterol-lowering effects of probiotics and prebiotics. In: Venema, K., Carmo, P.A., Probiotics and Prebiotics, 429-447.

Liu, J., Wang, Y., Li, A., Iqbal, M., Zhang, L., Pan, H., Liu, Z. and Li, J. 2020. Probiotic potential and safety assessment of Lactobacillus isolated from yaks, Microbial Pathogenesis, $145,104213$.

Maragkoudakis, P., Zoumpopoulou, G., Miaris, C., Kalantzopoulos, G., Pot, B. and Tsakalidou, E. 2006. Probiotic potential of Lactobacillus strains isolated from dairy products, International Dairy Journal, 16, 189-199.

Marchesi, J.R., Adams, D.H., Fava, F., Hermes, G.D., Hirschfield, G.M., Hold, G., Quraishi, M.N., Kinross, J., Smidt, H. and Tuohy, K.M. 2016. The gut microbiota and host health: a new clinical frontier, Gut, 65 (2), 330-339.

Marco, M.L., Pavan, S. and Kleerebezem, M. 2006. Towards understanding molecular modes of probiotic action, Current Opinion in Biotechnology, 17 (2), 204-210.

Mathur, H., Beresford, T.P. and Cotter, P.D. 2020. Health benefits of lactic acid bacteria (LAB) fermentates, Nutrients, 12 (6), 1679.

Morandi, S., Brasca, M., Andrighetto, C., Lombardi, A. and Lodi, R. 2006. Technological and molecular characterisation of Enterococci isolated from north-west Italian dairy products, International Dairy Journal, 16 (8), 867-875.

Mundy, L., Sahm, D. and Gilmore, M. 2000. Relationships between enterococcal virulence and antimicrobial resistance, Clinical Microbiology Reviews, 13 (4), 513.

Muñoz-Quezada, S., Chenoll, E., Vieites, J.M., Genovés, S., Maldonado, J., Bermúdez-Brito, M., Gomez-Llorente, C., Matencio, E., Bernal, M.J., Romero, F., Suárez, A., Ramón, D. and Gil, A. 2013. Isolation, identification and characterisation of three novel probiotic strains (Lactobacillus paracasei CNCM I-4034, Bifidobacterium breve CNCM I-4035 and Lactobacillus rhamnosus CNCM I4036) from the faeces of exclusively breast-fed infants, British Journal of Nutrition, 109 (2), 51-62. 
Osmanagaoglu, O., Kiran, F. and Ataoglu, H. 2010. Evaluation of in vitro probiotic potential of Pediococcus pentosaceus OZF isolated from human breast milk, Probiotics and Antimicrobial Proteins, 2 (3), 162-74.

Patil, M., Pal, A., Anand, T. and Ramana, K. 2010. Isolation and characterization of lactic acid bacteria from curd and cucumber, Indian Journal of Biotechnology, 9.

Reis, N.A., Saraiva, M.A., Duarte, E.A., de Carvalho, E.A., Vieira, B.B. and Evangelista-Barreto, N.S. 2016. Probiotic properties of lactic acid bacteria isolated from human milk, Journal of Applied Microbiology, 121 (3), 811-20.

Saitou, N. and Nei, M. 1987. The neighbor-joining method: a new method for reconstructing phylogenetic trees, Molecular Biology and Evolution, 4 (4), 406-425.

Schultz, M. 2008. Clinical use of E. coli Nissle 1917 in inflammatory bowel disease, Inflammatory Bowel Diseases, 14 (7), 1012-1018.

Sharma, C., Gulati, S., Thakur, N., Singh, B.P., Gupta, S., Kaur, S., Mishra, S.K., Puniya, A.K., Gill, J.P.S. and Panwar, H. 2017. Antibiotic sensitivity pattern of indigenous Lactobacilli isolated from curd and human milk samples, 3 Biotech, 7 (1), 53.

Soccol, C.R., Vandenberghe, L.P.d.S., Spier, M.R., Medeiros, A.B.P., Yamaguishi, C.T., Lindner, J.D.D., Pandey, A. and Thomaz-Soccol, V. 2010. The potential of probiotics: a review, Food Technology and Biotechnology, 48 (4), 413434.

Tamura, K., Nei, M. and Kumar, S. 2004. Prospects for inferring very large phylogenies by using the neighbor-joining method, Proceedings of the National Academy of Sciences of the United States of America, 101 (30), 11030.

Turchi, B., Mancini, S., Fratini, F., Pedonese, F., Nuvoloni, R., Bertelloni, F., Ebani, V.V. and Cerri, D. 2013. Preliminary evaluation of probiotic potential of Lactobacillus plantarum strains isolated from Italian food products, World Journal of Microbiology and Biotechnology, 29 (10), 1913-1922.

Vinderola, C.G. and Reinheimer, J. 2003. Lactic acid starter and probiotic bacteria: Comparative "in vitro" study of probiotic characteristics and biological barrier resistance, Food Research International, 36, 895-904.

Vizoso Pinto, M.G., Franz, C.M., Schillinger, U. and Holzapfel, W.H. 2006. Lactobacillus spp. with in vitro probiotic properties from human faeces and traditional fermented products, International Journal of Food Microbiology, 109 (3), 205-14.

Xia, A.-N., Meng, X.-S., Tang, X.-J., Zhang, Y.-Z., Lei, S.-M. and Liu, Y.-G. 2021. Probiotic and related properties of a novel lactic acid bacteria strain isolated from fermented rose jam, LWT, 136, 110327.

Yang, J., Cao, Y., Cai, Y. and Terada, F. 2010. Natural populations of lactic acid bacteria isolated from vegetable residues and silage fermentation, Journal of Dairy Science, 93 (7), 31363145 .

Yang, S. C., Lin, C. H., Sung, C. T., 2014, Antibacterial activities of bacteriocins: application in foods and pharmaceuticals, Front Microbiol., 5, 241.

Yılmaz, H. K. \& Derya İpek, K. (2021). Probiyotikler ve Kadın Sağlığı Üzerine Etkileri. Avrupa Bilim ve Teknoloji Dergisi, (23), 518-523. DOI: 10.31590/ejosat.827669

Yoğurtçu, N.N. (2011). "Tulum peynirinden enterokok suçlarının izolasyonu ve antibiyotik duyarlılıklarının belirlenmesi", Yüksek lisans tezi, SDÜ Fen Bilimleri Enstitüsü, Isparta, 70.
Zhou, J.S., Pillidge, C.J., Gopal, P.K. and Gill, H.S. 2005. Antibiotic susceptibility profiles of new probiotic Lactobacillus and Bifidobacterium strains, International Journal of Food Microbiology, 98 (2), 211-7.

Zoumpopoulou, G., Pot, B., Tsakalidou, E. and Papadimitriou, K. 2017. Dairy probiotics: Beyond the role of promoting gut and immune health, International Dairy Journal, 67, 46-60.

Zucko, J., Starcevic, A., Diminic, J., Oros, D., Mortazavian, A.M. and Putnik, P. 2020. Probiotic - friend or foe?, Current Opinion in Food Science, 32, 45-49. 